\title{
Combined Butalbital/Acetaminophen/Caffeine Overdose: Case Files of the Robert Wood Johnson Medical School Toxicology Service
}

\author{
Christopher Bryczkowski • Ann-Jeannette Geib
}

Published online: 26 September 2012

(C) American College of Medical Toxicology 2012

Keywords Butalbital · Acetaminophen · Caffeine . Hemodialysis · Overdose

\section{Case Presentation}

A 40-year-old woman with no previous medical problems presented to the Emergency Department (ED) $2 \mathrm{~h}$ after ingesting an unknown amount of Fioricet ${ }^{\circledR}$ (butalbital/acetaminophen/caffeine), oxycodone, and fentanyl patches about 90 min prior to emergency medical service (EMS) dispatch. The patient's husband reported they had had a fight, and he went down to the basement; when he came back upstairs, he found the patient unconscious with an empty pill bottle. A call to the patient's pharmacy by ED staff revealed that the patient had her prescription for butalbital/acetaminophen/caffeine tablets refilled 5 days earlier and that she had convinced the pharmacist to override the refill amount to dispense 540 tablets; according to the pharmacist, the patient stated she was going on a trip to Italy and needed a 6-month supply. EMS personnel removed a fentanyl patch (unknown strength) from her skin. The source of the fentanyl and the strength and formulation of the oxycodone were not recorded. Prehospital treatment included

This project was not funded.

This case has not been previously presented.

C. Bryczkowski · A.-J. Geib $(\bowtie)$

Department of Emergency Medicine,

Robert Wood Johnson Medical School,

125 Paterson St., MEB 104,

New Brunswick, NJ 08903, USA

e-mail: ajgeib@hotmail.com naloxone $4 \mathrm{mg}$ IV without any noticeable clinical response, insertion of a nasal trumpet, and initiation of bag-valve-mask ventilation. A fingerstick glucose was $137 \mathrm{mg} / \mathrm{dL}$.

On arrival to the ED, the patient was unconscious with the following vital signs: blood pressure, $98 / 54 \mathrm{mmHg}$; pulse, 72 beats/min; respiratory rate, 14 breaths/min; and pulse oximetry, $100 \%$ on a non-rebreather mask. Auscultation of her chest revealed clear but bilaterally diminished breath sounds and a regular cardiac rhythm without murmurs, rubs, or gallops. The patient's ventilation improved with jaw thrust, but, due to increased secretions, she was intubated within 10 min of ED arrival using etomidate and succinylcholine.

On further examination, she had palpable distal pulses, and her abdomen was soft and non-tender. The patient's pupils were $1-2 \mathrm{~mm}$ in diameter and sluggishly reactive to light. The patient was noted to be shivering prior to being fully exposed, and her skin was warm and dry, revealing no signs of traumatic injuries.

An ECG revealed a normal sinus rhythm at 86 beats per minute with a prolonged QTc interval $(504 \mathrm{~ms})$. An orogastric tube and Foley catheter were both inserted, with a large volume $(700 \mathrm{cc})$ of dark-colored urine quickly filling the Foley bag. Activated charcoal $50 \mathrm{~g}$ was administered via orogastric tube. Due to the reported large ingestion of acetaminophen and some initial uncertainty about the time of ingestion, an IV $N$-acetylcysteine (NAC) infusion was started according to the 21-h protocol, prior to obtaining serum acetaminophen level results. About $90 \mathrm{~min}$ after arrival ( $3 \mathrm{~h}$ after ingestion), the patient began having massive diuresis, producing 5,800 $\mathrm{cc}$ of urine over $1 \mathrm{~h}$. Due to concerns about the patient's reported fentanyl patch ingestion and the lack of knowledge regarding possible extended- 
release formulations, whole bowel irrigation with polyethylene glycol-balanced electrolyte solution was also initiated.

\section{What Is "Fioricet ${ }^{\circledR}$ "}

Fioricet ${ }^{\circledR}$ (Watson Laboratories, Inc) is a combination tablet consisting of $40 \mathrm{mg}$ of caffeine (1,3,7-trimethylxanthine), $325 \mathrm{mg}$ of acetaminophen, and $50 \mathrm{mg}$ of butalbital (5-allyl5 -isopropylbarbituric acid). Fioricet ${ }^{\circledR}$ is primarily intended as treatment for tension headaches [1].

Caffeine is a methylxanthine similar to theophylline and theobromine. While caffeine is used for stimulant and mood-elevating effects in drinks such as coffee, it also has been used to treat neonatal apnea and headaches in combination with other analgesics. Theophylline has classically been used to treat bronchospastic airway diseases such as asthma and COPD, although it has generally fallen out of favor to pure $\beta$-adrenergic agonists due to their better safety profiles [2]. As a group, methylxanthines cause the release of catecholamines, which subsequently stimulate $\beta_{1}$ and $\beta_{2}$ receptors, accounting for their stimulant effects. Methylxanthines' role in treating bronchospastic disease is due to both bronchodilatory and anti-inflammatory mechanisms. Toxic concentrations of caffeine (such as those achieved with oral doses $>1 \mathrm{~g}$ ) inhibit phosphodiesterase and thus increase levels of cAMP, promoting central nervous system (CNS) excitation, peripheral vasodilation, myocardial stimulation, and smooth muscle relaxation [3]. In addition, methylxanthines antagonize the benzodiazepine receptor, which likely contributes to the refractoriness of seizures from toxicity from these agents.

Acetaminophen, the second ingredient in Fioricet ${ }^{\circledR}$, inhibits the synthesis of prostaglandins and hypothalamic heat regulation in the CNS and blocks peripheral pain impulses. Finally, butalbital is a short-to-intermediate acting barbiturate. The effects of butalbital in isolation are not well understood, as it is only available in combination products. Barbiturates have muscle-relaxing and anti-anxiety properties. A reason for butalbital's use in conjunction with caffeine may be to antagonize the unwanted central stimulating effect of caffeine [4].

\section{How Do Methylxanthines Cause Systemic Toxicity?}

When ingested orally, caffeine has nearly $100 \%$ bioavailability and produces peak plasma concentrations within 3060 min following ingestion. The amount of caffeine in a cup of coffee varies by volume in the "cup," the strength and method of brewing, and the roasting of coffee beans; however, a typical 5-ounce $(150 \mathrm{ml})$ cup of brewed coffee will contain around $85 \mathrm{mg}$ caffeine [5]. Mean plasma caffeine concentrations reach around $12 \mathrm{mg} / \mathrm{L}$ after ingesting $250 \mathrm{mg}$ of caffeine [6]. Toxicity is generally associated with plasma concentrations $>30 \mathrm{mg} / \mathrm{L}[3,6,7]$. While the fatal oral dose of caffeine is likely around $10 \mathrm{~g}$, the highest reported ingestion to have been survived is $24 \mathrm{~g}$, (plasma concentration, $200 \mathrm{mg} / \mathrm{L}$ ) [7, 8]. Death has been reported from intravenous injection of $3.2 \mathrm{~g}$ of caffeine [9]. Methylxanthine toxicity causes nausea, vomiting, mental status changes, seizures, hypotension, and dysrhythmias. Ingestions involving combination tablets with butalbital can additionally induce respiratory depression, thus, gaining early control of a patient's airway is a priority.

Toxicity within the gastrointestinal tract can cause nausea and vomiting. Emesis is often the most predominant symptom, occurring in 71-100\% of acute intoxications and may be difficult to control [10-12, 42]. Furthermore, methylxanthines promote gastric acid secretion, and their smooth muscle relaxing effects contribute to both gastritis and esophagitis, as seen with chronic use [13, 34].

Multiple mechanisms have been suggested for the arrhythmogenic capability of methylxanthines. Caffeine has been shown to cause a strong release of circulating catecholamines from the adrenal medulla, predominantly epinephrine [3, 14, 34]. Catecholamines stimulate the $\beta_{1}$ adrenoreceptor, augmenting the production of cyclic adenosine monophosphate (cAMP) by adenylate cyclase. Caffeine also can inhibit the degradation of cAMP by phosphodiesterase, further augmenting intracellular cAMP levels and inducing cardiac dysrhythmias [6, 15-17]. Additionally, caffeine induces calcium release from the sarcoplasmic reticulum into the cytosol and then quickly inhibits calcium's re-uptake back into the sarcoplasmic reticulum. The increased calcium concentrations may then provoke dysrhythmias [17-21]. Finally, caffeine may induce dysrhythmias by blocking cardiac adenosine $\mathrm{A}_{2}$ receptors, whose action has been shown to be antiarrhythmic [22]. Increased calcium concentration within muscles causes greater contractility and contributes to tremor, a common side effect. This, along with increased muscular activity during methylxanthine-induced seizures, may lead to rhabdomyolysis [23].

The hypotension that may be seen following methylxanthine overdose is believed to have two mechanisms. First, methylxanthines induce tachydysrhythmias. The increase in heart rate leads to inadequate filling of the heart, ultimately leading to a drop in cardiac output. Second, increased circulating catecholamines stimulate $\beta_{2}$ adrenoreceptors in vascular smooth muscle, resulting in vasodilation and hypotension $[3,24,25]$. By carrying additional methyl groups, caffeine has greater CNS penetration relative to other methylxanthines and has been able to cause prolonged seizures $[24,62]$. Under normal conditions, adenosine receptor $A_{1}$ stimulation is responsible in terminating seizure activity. Likewise, stimulation of adenosine receptor $\mathrm{A}_{2}$ enhances blood flow to the brain during seizures via cerebral 
vasodilatation. During methylxanthine intoxication, the increased metabolic demand from seizures may not be met by an increase in cerebral blood flow, due to vasoconstriction, allowing hypoxia to contribute to prolonged seizures [24, 62]. Furthermore, caffeine has been found to be a competitive antagonist of benzodiazepines at the benzodiazepine receptor and may contribute to the seizures' intractability [3]. Caffeine has been documented to cause anxiety, confusion, and delirium as well [30].

Caffeine toxicity may be accompanied by hypokalemia, hypomagnesemia, and hypophosphatemia [8, 31]. Hypokalemia is the most frequent electrolyte derangement reported, occurring to some degree in almost all cases of acute methylxanthine overdose $[32,33]$. Prolonged $\beta_{2}$ adrenergic agonism from high circulating concentrations of catecholamines, particularly epinephrine, will result in a shift of serum potassium into the intracellular compartment, while keeping total body stores normal $[3,8,32,34]$. Likewise, aminophylline infusions cause elevations in plasma insulin levels, which may exacerbate this derangement $[35,36]$. While gastrointestinal losses could be another contributing cause, hypokalemia has been shown to precede emesis and has occurred in cases without emesis [33]. Vomiting may, however, contribute to ongoing fluid losses. Hyperglycemia, hyperinsulinemia, leukocytosis, metabolic acidosis, and ketosis have also been reported [3, 8]. Elevated levels of cAMP presumably via both increased catecholamines and phosphodiesterase inhibition have been shown to stimulate hepatic glucose production and pancreatic insulin release [32, 37, 38]. High levels of both epinephrine and norepinephrine may lead to lactic acidosis by compromising peripheral tissue oxygen supply via vasoconstriction and reducing hepatic clearance of lactate through changes in hepatic blood flow [31,39, 40].

\section{Case Continuation}

The initial set of laboratory values was significant for a metabolic acidosis with hypokalemia (Table 1). The patient began to have a seizure about $1 \mathrm{~h}$ after arrival, and she was treated with $2 \mathrm{mg}$ IV lorazepam, then another $4 \mathrm{mg}$ lorazepam with control of the seizures, and then sedated with a propofol infusion at $30 \mathrm{mcg} / \mathrm{kg} / \mathrm{min}$. The patient's rectal temperature was noted to be $34.4{ }^{\circ} \mathrm{C}$, and she was treated with warm IV fluids and a forced warm-air blanket. The serum acetaminophen level was $153.8 \mu \mathrm{g} / \mathrm{mL}$ (normal, 10 $30 \mu \mathrm{g} / \mathrm{mL}$ ), ethyl alcohol was $<5.0 \mathrm{mg} / \mathrm{dL}$, and the salicylate level was $<4.0 \mathrm{mg} / \mathrm{dL}$. A routine urine drug screen was positive for barbiturates and negative for benzodiazepines, cocaine, opiates, and tetrahydrocannabinol. The patient's subsequent 2-h urine output was $6 \mathrm{~L}$, which was matched by IV fluid volume administration. Given the patient's critical clinical condition, and without a readily available caffeine
Table 1 Laboratory test results

\begin{tabular}{|c|c|c|}
\hline Test & Result & Reference value \\
\hline $\begin{array}{l}\text { White blood cell } \\
\text { count (WBC) }\end{array}$ & $9.4 \mathrm{k} / \mu \mathrm{L}$ & $4-10.5 \mathrm{k} / \mu \mathrm{L}$ \\
\hline Hemoglobin (Hg) & $13.9 \mathrm{~g} / \mathrm{dL}$ & $12-15 \mathrm{~g} / \mathrm{dL}$ \\
\hline Hematocrit (Hct) & $41.8 \%$ & $36-46 \%$ \\
\hline Platelets & $288 \mathrm{k} / \mu \mathrm{L}$ & $150-400 \mathrm{k} / \mu \mathrm{L}$ \\
\hline Sodium $(\mathrm{Na})$ & $133 \mathrm{mEq} / \mathrm{L}$ & $135-145 \mathrm{mEq} / \mathrm{L}$ \\
\hline Potassium (K) & $2.6 \mathrm{mEq} / \mathrm{L}$ & $3.5-5 \mathrm{mEq} / \mathrm{L}$ \\
\hline Chloride $(\mathrm{Cl})$ & $108 \mathrm{mEq} / \mathrm{L}$ & $96-112 \mathrm{mEq} / \mathrm{L}$ \\
\hline Bicarbonate $\left(\mathrm{HCO}_{3}\right)$ & $19.1 \mathrm{mEq} / \mathrm{L}$ & 24-32 mEq/L \\
\hline $\begin{array}{l}\text { Blood urea } \\
\text { nitrogen (BUN) }\end{array}$ & $19 \mathrm{mg} / \mathrm{dL}$ & $6-23 \mathrm{mg} / \mathrm{dL}$ \\
\hline Creatinine $(\mathrm{Cr})$ & $0.7 \mathrm{mg} / \mathrm{dL}$ & $0.4-1.2 \mathrm{mg} / \mathrm{dL}$ \\
\hline Glucose & $133 \mathrm{mg} / \mathrm{dL}$ & $70-100 \mathrm{mg} / \mathrm{dL}$ \\
\hline Calcium (Ca) & $8.9 \mathrm{mg} / \mathrm{dL}$ & $0.6-10.4 \mathrm{mg} / \mathrm{dL}$ \\
\hline Anion gap & $12.9 \mathrm{mEq} / \mathrm{L}$ & $7-15 \mathrm{mEq} / \mathrm{L}$ \\
\hline Protein & $7.1 \mathrm{~g} / \mathrm{dL}$ & $6-8 \mathrm{~g} / \mathrm{dL}$ \\
\hline Albumin & $4.3 \mathrm{~g} / \mathrm{dL}$ & $3.5-5.5 \mathrm{~g} / \mathrm{dL}$ \\
\hline Bilirubin, total & $0.7 \mathrm{mg} / \mathrm{dL}$ & $0.1-1.2 \mathrm{mg} / \mathrm{dL}$ \\
\hline Alkaline phosphatase & $59 \mathrm{IU} / \mathrm{L}$ & 37-107 IU/L \\
\hline $\begin{array}{l}\text { Alanine aminotransferase } \\
\text { (ALT) }\end{array}$ & $21 \mathrm{IU} / \mathrm{L}$ & 3-40 IU/L \\
\hline $\begin{array}{l}\text { Aspartate aminotransferase } \\
\text { (AST) }\end{array}$ & $22 \mathrm{IU} / \mathrm{L}$ & $12-45 \mathrm{IU} / \mathrm{L}$ \\
\hline Magnesium & $1.6 \mathrm{mg} / \mathrm{dL}$ & $1.8-2.5 \mathrm{mg} / \mathrm{dL}$ \\
\hline Lactate & $3.2 \mathrm{mmol} / \mathrm{L}$ & $0.5-2.2 \mathrm{mmol} / \mathrm{L}$ \\
\hline CPK & $121 \mathrm{IU} / \mathrm{L}$ & $25-150 \mathrm{IU} / \mathrm{L}$ \\
\hline CKMB & [Not performed] & $0.0-6.3 \mathrm{ng} / \mathrm{mL}$ \\
\hline Troponin I & $<0.01 \mathrm{ng} / \mathrm{mL}$ & $0.00-0.50 \mathrm{ng} / \mathrm{mL}$ \\
\hline $\mathrm{pH}$ & 7.21 & $7.36-7.42$ \\
\hline $\mathrm{pCO}_{2}$ & $34 \mathrm{mmHg}$ & $25-45 \mathrm{mmHg}$ \\
\hline Total $\mathrm{CO}_{2}$ & $14.0 \mathrm{mEq} / \mathrm{L}$ & $24-32 \mathrm{mEq} / \mathrm{L}$ \\
\hline $\mathrm{p} 0_{2}$ & $121 \mathrm{mmHg}$ & $80-115 \mathrm{mmHg}$ \\
\hline $\mathrm{O}_{2}$ Saturation & $\begin{array}{l}96.9 \% \\
\quad\left(\mathrm{FiO}_{2}=100 \%\right)\end{array}$ & $94-100 \%$ \\
\hline
\end{tabular}

assay, a hemodialysis catheter was inserted for emergent dialysis due to presumed severe caffeine toxicity.

\section{Is Hemoperfusion Still a Viable Alternative to Modern-Day Hemodialysis?}

Caffeine is primarily metabolized via demethylation by CYP 1A2, with plasma protein binding of $36 \%$ and a volume of distribution of $0.5 \mathrm{~L} / \mathrm{kg}$ [24, 41]. Because of its low volume of distribution, caffeine is amenable to extracorporeal methods of elimination. Charcoal hemoperfusion has traditionally been regarded as the method of choice for enhanced elimination of methylxanthines, particularly theophylline $[42,43]$. While the endogenous rate of theophylline 
clearance has been demonstrated to be approximately 50 $\mathrm{mL} / \mathrm{min}$, hemoperfusion derived rates have been reported up to four to six times higher [42, 44, 45]. Hemodialysis, while used, has historically had substantially lower clearance rates (around $100 \mathrm{~mL} / \mathrm{min}$ ) compared with hemoperfusion [43, 46-49].

Nonetheless, advances in modern-day hemodialysis now allow for much greater flow rates (as high as $300 \mathrm{~mL} / \mathrm{min}$ ) and a potential increase in methylxanthine clearance. Furthermore, hemodialysis offers additional advantages such as correcting electrolyte derangements and fluid balance, both of which are common issues in methylxanthine toxicity. Hemodialysis also has a better safety profile in comparison to hemoperfusion. In a study of those undergoing hemoperfusion for theophylline toxicity, complication rates of $18 \%$ have been observed, involving bleeding diatheses, thrombocytopenia, and hypocalcemia, versus $0 \%$ with hemodialysis [42]. This study failed to demonstrate a significant clinical advantage of hemoperfusion over hemodialysis, while both methods had comparable reductions in morbidity and mortality [42]. Because hemodialysis equipment and trained personnel are more readily available, hemoperfusion has fallen out of favor as an enhanced elimination modality.

Another limitation to hemoperfusion is cartridge saturation. While the initial drug extraction efficacy of each charcoal hemoperfusion cartridge begins near $100 \%$, it drops close to $65 \%$ after 90 min of use, becoming less efficient than hemodialysis. As a result, single-use cartridges need to be replaced about every $2 \mathrm{~h}$ to maintain efficacy of the treatment $[44,50]$. In an effort to slow the rate of cartridge saturation, modalities such as serial hemodialysis and hemoperfusion have been employed. By utilizing this method, extraction efficacy greater than $94 \%$ at $60 \mathrm{~min}$ has been reported [50]. The use of both modalities in tandem thus offers not only enhanced clearance but also correction of electrolyte imbalances, and prolongs the life of the charcoal hemoperfusion cartridge and has been shown to offer advantages to either method alone.

\section{What Are the Indications for Hemodialysis or Hemoperfusion for Methylxanthine Toxicity?}

Most guidelines developed for enhanced elimination of methylxanthines have primarily focused on theophylline. The therapeutic serum concentration of theophylline is between 10 and $20 \mu \mathrm{g} / \mathrm{mL}$. It has a narrow therapeutic window, with $>75 \%$ of patients exhibiting adverse reactions with levels greater than $25 \mu \mathrm{g} / \mathrm{mL}$ [51]. The risk of side effects increases with higher theophylline concentrations, and the majority of seizures occur in patients with concentrations greater than $40 \mu \mathrm{g} / \mathrm{mL}$ [52-54]. Further reports suggest that peak serum theophylline concentrations were a predictor of toxicity [55-57]. Even so, no consensus guidelines existed for when to employ hemoperfusion, with threshold serum theophylline levels ranging from 330 (59.4) to $550 \mu \mathrm{mol} / \mathrm{L}(99 \mu \mathrm{g} / \mathrm{mL})[10,58,59]$. Recommendations made by Park et al. and revised by Goldberg et al. suggest that hemoperfusion be performed in patients with a serum theophylline concentration greater than $80 \mu \mathrm{g} / \mathrm{mL}$ following an acute intoxication and in those with a serum level greater than $60 \mu \mathrm{g} / \mathrm{mL}$ with a chronic ingestion. They further suggested that those who could not tolerate oral charcoal were older than 60 years of age or had concurrent heart and liver dysfunction were at increased risk [58-61]. Extracorporeal elimination should be begun prior to onset of major toxicity involving seizures or dysrhythmias, since once these complications are present the use of enhanced elimination has not been shown to terminate such events [42].

While the toxicity from other methylxanthines, such as caffeine, should be managed in a similar manner, quantitative caffeine levels are less commonly available than theophylline levels in an acute setting. Nonetheless, with massive caffeine ingestions, a considerable amount of caffeine may be metabolized to theophylline, resulting in detectable, and in some cases, nearly toxic, theophylline levels [8]. With caffeine overdose, obtaining a theophylline level may at the least confirm the class of ingestant and help guide management. In general, in the treatment of systemic toxicity, the patient's clinical picture (e.g., persistent seizures, cardiac dysrhythmias, hemodynamic instability) is the most important factor when deciding whether to utilize enhanced methods of elimination.

\section{Case Continuation}

The patient was transferred from the ED to the medical intensive care unit (MICU) where she continued to have large volume diuresis while concurrently undergoing emergent hemodialysis. At the completion of dialysis, the patient was given an additional loading dose of $\mathrm{N}$-acetylcysteine over $1 \mathrm{~h}$ and then subsequent doses as per the 21-h NAC protocol. As the patient's urine output over the next $6 \mathrm{~h}$ was as high as $1,200 \mathrm{~mL} / \mathrm{hr}$, the MICU resident ordered administration of desmopressin $1 \mu \mathrm{g}$. During the subsequent $6 \mathrm{~h}$, the patient's urine output dropped to an average of $550 \mathrm{~mL} / \mathrm{h}$. Potassium and magnesium were supplemented, and serum concentrations normalized. The patient was extubated the following morning.

The initial pre-dialysis caffeine level result was $51.2 \mu \mathrm{g} /$ $\mathrm{mL}$ with a repeat the following morning (after dialysis) of $4.1 \mu \mathrm{g} / \mathrm{mL}$. The patient ultimately admitted to ingesting around 100 tablets of Fioricet ${ }^{\circledR}$ in addition to her daily dose of oxycodone but denied ingesting any fentanyl patches. She had stated her intent was for recreational and "escape" purposes, rather than suicidal intent. The patient was 
transferred out of the MICU, was seen by psychiatry, and was ultimately discharged 3 days post-ingestion without any noted neurologic sequelae.

\section{What is the Role of $\mathrm{N}$-acetylcysteine (NAC) in Patients Being Dialyzed for Another Indication? Does NAC Get Dialyzed Away?}

$\mathrm{N}$-Acetylcysteine has long been used in the treatment of acetaminophen overdose. Its main efficacy comes in its ability to stimulate glutathione synthesis [62]. By repleting glutathione, NAC works to prevent the binding of $N$-acetyl-p-benzoquinoneimine to hepatocytes with subsequent necrosis. In this case, as the patient's time of ingestion was unknown, she was promptly given the standard $150 \mathrm{mg} / \mathrm{kg}$ loading dose of NAC. However, when the patient underwent dialysis for caffeine toxicity, it was not clear what would happen to the NAC that had already been infused, and therefore whether the patient required a repeat NAC loading dose or not.

NAC has a volume of distribution of about $0.5 \mathrm{~L} / \mathrm{kg}$, is about $83 \%$ protein-bound, and has a mean half-life of about 6 h. $70 \%$ of its total body clearance is non-renal [63-65]. While it has a relatively small volume of distribution, the high protein-bound percentage of NAC makes it unclear whether it can readily cross a dialysis membrane. In patients with renal insufficiency undergoing hemodialysis, it has been reported that about half of NAC given during dialysis should be replaced. In instances where such patients have concurrent acetaminophen poisoning, it has been recommended that they receive a supplemental dose of NAC at the end of their dialysis session [66]. To the best of our knowledge, there are no reports directly measuring NAC concentrations in otherwise healthy individuals subsequently undergoing hemodialysis. As a result, we elected to give our patient a supplemental loading dose of IV NAC following hemodialysis.

\section{What Is the Role of Vasopressin or DDAVP in Caffeine Toxicity?}

Vasopressin possesses many properties that can counteract effects seen with caffeine toxicity. Arginine-vasopressin (AVP) is endogenously released from the posterior pituitary gland in response to reduced plasma volume or increased serum osmolality and is most commonly regarded to as the anti-diuretic hormone [67]. Under normal conditions, its major role is in the regulation of water balance. Vasopressin has affinity for $\mathrm{V}_{1}$ (vascular) and $\mathrm{V}_{2}$ (renal) receptors. $\mathrm{V}_{1}$ receptors are present on vascular smooth muscle. Their stimulation induces phosphatidylinositol turnover and mediates vasoconstriction by releasing calcium from intracellular stores [24, 68-70]. This directly inhibits the adenylate cyclase-mediated vasodilation caused by caffeine. Not surprisingly, the use of intravenous vasopressin as a pressor agent in massive caffeine overdose has been described [24]. Conversely, while being a potent vasoconstrictor in skin and skeletal muscle, vasopressin has been shown to produce vasodilation in renal, pulmonary, mesenteric, and cerebral circulations. This is most likely due to endothelial NO release [71-75]. Vasopressin-induced cerebral dilation may work to oppose caffeine ( $\mathrm{A}_{2}$ blockade) induced vasoconstriction.

Vasopressin $V_{2}$ receptors are present in renal endothelial cells and the collecting duct system. Their stimulation results in a rise in cAMP via activation of adenylate cyclase $[69,76$, 77]. Rising cAMP levels cause an increase in water permeability of the apical membrane and trigger the release of more water channels to appear on its surface. This results in increased reabsorption of water and concurrent decrease in urine output [76-80]. S1-Desamino-8-D-arginine vasopressin (DDAVP), or desmopressin, is a synthetic vasopressin with antidiuretic properties and little to no vasopressor effect [81]. Desmopressin has affinity for the $\mathrm{V}_{2}$ receptor 1.6 times that of AVP [82]. Thus, DDAVP administration may have benefit in counteracting caffeine-induced diuresis. In our patient, urine output dropped $50 \%$ following a $1 \mu \mathrm{g}$ desmopressin dose.

\section{What Is the Role of $\beta$ Blockers in Methylxanthine Toxicity?}

Hypotension is a common complication in methylxanthine toxicity. This effect is primarily due to $\beta_{1}$ receptor-mediated tachydysrhythmias and $\beta_{2}$-receptor-mediated vascular smooth muscle vasodilation [3, 24, 25]. Treatment of such hypotension has the possibility of being refractory to IV fluids and standard vasopressor therapy [83]. Consequently, the use of nonselective $\beta$-blockers such as propranolol has been used in theophylline toxicity [84-86]. By blocking $\beta_{1^{-}}$stimulated tachycardia, propranolol is able to increase end diastolic filling and subsequently, blood pressure. At the same time, propranolol has been observed to improve blood pressure in patients with persistent tachycardia, suggesting the probable importance of its ability also to block $\beta_{2^{-}}$ mediated vasodilation. Propranolol is also able to counteract catecholamine-induced tachydysrhythmias, tremor, and agitation-all of which are likely to occur in caffeine toxicity [87]. While successful in their ability to ameliorate the toxic effects of caffeine, the safety of nonselective $\beta$-blockers has been questioned in patients with asthma or chronic obstructive pulmonary disease [85-87]. The use of $\beta_{1}$-selective $\beta$ blockers such as esmolol has been described.

With a half-life of $9 \mathrm{~min}$, esmolol is a short-acting $\beta_{1^{-}}$selective $\beta$ blocker [88]. Its main benefit is thought to be inhibition of $\beta_{1}$ cardiac receptors, blocking catecholamineinduced tachycardia. At doses adequate to produce $\beta_{1}$ 
blockade, there has been no noticeable effect on $\beta_{2}$ receptors. Not surprisingly, esmolol has been safely used in patients with asthma $[89,90]$. Esmolol offers the advantage of having a short duration of clinical effect, making it easily titratable. No significant persistent drug effects have been evident 30 min following its discontinuation [91]. Nevertheless, it has been reported that continued treatment $(>1 \mathrm{~h})$ with $\beta$-blocking agents such as esmolol for persistent tachycardia can cause a decrease in cardiac index and result in cardiogenic shock, although not all reports reached the same conclusion [86, 91]. As a result, the use of continuous hemodynamic monitoring should be stressed. Still, $\beta$ blocker use in caffeine toxicity may restore hemodynamic stability in an otherwise unstable patient.

\section{Was This Patient Relatively Protected from Methylxanthine Neurotoxicity by the Presence of Barbiturates (Butalbital) Found in the Fioricet ${ }^{\circledR}$ ?}

Methylxanthine-induced neurotoxicity is most manifestly evident by the presence of seizures occurring due to adenosine $A_{1}$ and $A_{2}$ receptor antagonism within the brain [24-29]. The mainstay of treatment for methylxanthine-induced seizures has been the use of benzodiazepines and barbiturates, with diazepam and phenobarbital frequently being described as effective agents [54, 92]. In fact, diazepam, clonazepam, valproic acid, and phenobarbital have all been found to be of benefit in their ability to increase the CNS threshold for methylxanthine-induced, particularly theophylline-induced, seizures. In contrast, phenytoin had no such effect, and does not serve a role in treatment $[92,93]$. The use of phenobarbital in theophylline-intoxicated rats has been described to prevent seizures and improve survival (from $20 \%$ to $50 \%$ ) [92]. We hypothesize that the presence of butalbital within the Fioricet ${ }^{\circledR}$ may have exhibited a neuroprotective effect on our patient. While she did have a seizure, it was terminated by the use of modest doses of lorazepam without occurrence of further episodes. In addition, she made complete recovery to her baseline mental status. Nonetheless, it cannot be overlooked that use of propofol infusion may have served as a confounder.

Conflict of Interest We have no conflicts to report.

\section{References}

1. DailyMed. US. National Library of Medicine, National Institute of Health (2011) "FIORICET (butalbital, acetaminophen, and caffeine) Tablet." DailyMed. US. National Library of Medicine, National Institute of Health Web http://dailymed.nlm.nih.gov/dailymed/ lookup.cfm?setid=a03276eb-d435-4159-9cc8-70c2ed132882. Accessed 7 June 2012
2. Murciano D, Auclair MH, Pariente R, Aubier M (1989) A randomized, controlled trial of theophylline in patients with severe chronic obstructive pulmonary disease. N Engl J Med 320:15211525

3. Pentel P (1984) Toxicity of over-the-counter stimulants. JAMA 252(14):1898-1903

4. Solomon S (2002) Butalbital-containing agents: should they be banned? No. Curr Pain Headache Rep 6(2):147-150

5. McCusker RR, Goldberger BA, Cone EJ (2003) Caffeine content of specialty coffees. J Anal Toxicol 27:520-522

6. Robertson D, Frolich SC, Carr RK et al (1978) Effects of caffeine on plasma renin activity, catecholamines and blood pressure. N Engl J Med 298:181-186

7. "Caffeine" in Drug Monographs. Access medicine. 1978. McGraw-Hill Companies. http://www.accessmedicine.com. libproxy2.umdnj.edu/drugContent.aspx?mid=5782. Accessed 30 August 2012

8. Benowitz NL, Osterloh J, Goldschlager N et al (1982) Massive catecholamine release from caffeine poisoning. JAMA 248 (9):1097-1098

9. Jokela S, Vartiainen A (1959) Caffeine poisoning. Acta Pharmacol Toxicol 15(4):331-334

10. Shannon M (1993) Predictors of major toxicity after theophylline overdose. Ann Intern Med 119(12):1161-1167

11. Amitai V, Lovejoy FH Jr (1987) Characteristics of vomiting associated with acute sustained release theophylline poisoning: implications for management with oral activated charcoal. J Toxicol Clin Toxicol 25(7):539-554

12. Sessler CN, Glauser FL, Cooper KR (1985) Treatment of theophylline toxicity with oral activated charcoal. Chest $87(3): 325$ 329

13. Cohen S, Booth GH Jr (1975) Gastric acid secretion and loweresophageal-sphincter pressure in response to coffee and caffeine. N Engl J Med 293:897-899

14. Kearney T, Manoguerra A, Curtis G et al (1985) Theophylline toxicity and the beta-adrenergic system. Ann Intern Med 102 (6):766-769

15. Benowitz NL (1990) Clinical pharmacology of caffeine. Ann Rev Med 41:277-288

16. Abbott PJ (1986) Caffeine: a toxicological overview. Med J Aust 145(10):518-521

17. Myers MG (1991) Caffeine and cardiac arrhythmias. Ann Intern Med 114(2):147-150

18. Lin CI, Vassalle M (1983) Role of calcium in the inotropic effects of caffeine in cardiac Purkinje fibers. Int J Cardiol 3(4):421-434

19. Paspa P, Vassalle M (1984) Mechanism of caffeine-induced arrhythmias in canine cardiac Purkinje fibers. Am J Cardiol 53 (2):313-319

20. Boutjdir M, el-Sherif N, Gough WB (1990) Effects of caffeine and ryanodine on delayed afterdepolarizations and sustained rhythmic activity in 1-day-old myocardial infarction in the dog. Circulation 81(4):1393-1400

21. Hess P, Wier WG (1984) Excitation-contraction coupling in cardiac Purkinje fibers: effects of caffeine on the intracellular [Ca2p] transient, membrane currents, and contraction. J Gen Physiol 83 (3):417-433

22. Schreieck J, Richardt G (1999) Endogenous adenosine reduces the occurrence of ischemia-induced ventricular fibrillation in rat heart. L Mol Cell Cardiol 31(1):123-134

23. Wrenn KD, Oschner I (1989) Rhabdomyolysis induced by a caffeine overdose. Ann Emerg Med 18(1):94-97

24. Holstege CP, Hunter Y, Baer A (2003) Massive caffeine overdose requiring vasopressin infusion and hemodialysis. J Clin Toxicol 41 (7):1003-1007

25. Holstege CP, Dobmeier S (2005) Cardiovascular challenges in toxicology. Emerg Med Clin N Am 23(4):1195-1217 
26. Datto C, Rai AK, Ilivicky HJ, Caroff SN (2002) Augmentation of seizure induction in electroconvulsive therapy: a clinical reappraisal. J ECT 18(3):118-125

27. Shannon M, Maher T (1995) Anticonvulsant effects of intracerebroventricular Adenocard in theophylline-induced seizures. Ann Emerg Med 26(1):65-68

28. Eldrige FL, Paydarfar D, Scott SC, Dowell RT (1989) Role of endogenous adenosine in recurrent generalized seizures. Exp Neurol 103(2):179-185

29. Young D, Dragunow M (1994) Status epilepticus may be caused by loss of adenosine anticonvulsant mechanisms. Neuroscience 58 (2):245-261

30. Stillner V, Popkin MK, Pierce CM (1978) Caffeine-induced delirium during prolonged competitive stress. Am J Psychiatry 135 (7):855-856

31. Bernard S (1991) Severe lactic acidosis following theophylline overdose. Ann Emerg Med 20(10):1135-1137

32. Hall KW, Dobson KE, Dalton JG et al (1984) Metabolic abnormalities associated with intentional theophylline overdose. Ann Intern Med 101(4):457-462

33. Amitai U, Lovejoy FH Jr (1988) Hypokalemia in acute theophylline poisoning. Am J Emerg Med 6(3):214-218

34. Brown MJ, Brown DC, Murphy MB (1983) Hypokalemia from beta2-receptor stimulation by circulating epinephrine. N Engl J Med 309:1414-1419

35. Vestal RE, JR Eiriksson CE, Musser B et al (1983) Effect of intravenous aminophylline on plasma levels of catecholamines and related cardiovascular and metabolic responses. Circulation 67(1):162-167

36. Ensinck JW, Stoll RW, Gale CC et al (1970) Effect of aminophylline on the secretion of insulin, glucagon, luteinizing hormone and growth hormone in humans. J Clin Endocrinol 31(2):153-161

37. Exton JH, Park CR (1968) Control of gluconeogenesis in the liver: II. Effects of glucagon, catecholamines and adenosine 3', 5' monophosphate on gluconeogenesis in the perfused rat liver. Biol Chem 243(16):4289-4296

38. Brisson GR, Malaisse-Lagae F, Malaisse WJ (1972) The stimulussecretion coupling of glucose-induced insulin release: VII. A proposed site of action for adenosine- $3^{\prime} 5^{\prime}$ cyclic monophosphate. Clin Invest 51(2):232-241

39. Madias NE, Goorno WE, Herson S (1987) Severe lactic acidosis as a presenting feature of pheochromocytoma. Am J Kidney Dis 10 (3):250-253

40. Bornemann M, Hill SC, Kidd GS (1986) Lactic acidosis in pheochromocytoma. Ann Intern Med 105(6):880-882

41. Bonati M, Latini R, Galletti F et al (1982) Caffeine disposition after oral doses. Clin Pharmacol Ther 32(1):98-106

42. Shannon MW (1997) Comparative efficacy of hemodialysis and hemoperfusion in severe theophylline intoxication. Acad Emerg Med 4(7):674-678

43. Sahney S, Abarzua J, Sessums L (1983) Hemoperfusion in theophylline neurotoxicity. Pediatrics 71(4):615-619

44. Ehlers SM, Zaske DE, Sawchuck RJ (1978) Massive theophylline overdose: rapid elimination by charcoal hemoperfusion. JAMA 240(5):474-475

45. Russo ME (1979) Management of theophylline intoxication with charcoal-column hemoperfusion. N Engl J Med 300:24-26

46. Zimmerman PM, Pulliam J, Schwengels J, MacDonald SE (1985) Caffeine intoxication: a near fatality. Ann Emerg Med 14 (12): $1227-1229$

47. Heath A, Knudsen K (1987) Role of extracorporeal drug removal in acute theophylline poisoning - a review. Med Toxicol 2(4):294-308

48. Lee CS, Marbury TC, Perrin JN (1979) Hemodialysis of theophylline in uremic patients. J Clin Pharmacol 19(4):219-226

49. Levy G, Gibso TP, Whitman W et al (1977) Hemodialysis clearance of theophylline. JAMA 237(14):1466-1467
50. Hootkins R, Lerman MJ, Thompson JR (1990) Sequential and simultaneous "in series" hemodialysis and hemoperfusion in the management of theophylline intoxication. J Am Soc Nephrol 1 (6):923-926

51. Jacobs MH, Senior RM, Kessler G (1976) Clinical experience with theophylline. Relationship between dosage, serum concentration and toxicity. JAMA 235(18):1983-1986

52. Hendeles L, Bighley L, Richardson RH et al (2006) Frequent toxicity from IV aminophylline infusions in critically ill patients. Ann Pharmacother 40(7-8):1417-1423

53. Burkle WS, Gwizdala CJ (1981) Evaluation of 'toxic' serum theophylline concentration. Am J Hosp Pharmacol 38(8):1164 1166

54. Paloucek FP, Rodvold KA (1988) Evaluation of theophylline overdoses and toxicities. Ann Emerg Med 17(2):135-144

55. Murciano D, Auclair MH, Pariente R, Aubier M (1990) A randomized, controlled trial of theophylline in patients with severe chronic obstructive pulmonary disease. N Engl J Med 320:15211525

56. Sessler CN (1990) Theophylline toxicity: clinical features of 116 consecutive cases. Am J Med 88(6):567-576

57. Gaudreauit P, Wason S, Lovejoy FH Jr (1983) Acute pediatric theophylline overdose: a summary of 28 cases. J Pediatr 102 (3):474-476

58. Park GD, Spector R, Roberts RJ et al (1983) Use of hemoperfusion for treatment of theophylline intoxication. Am J Med 74(6):961966

59. Goldberg MJ, Park GD, Berlinger WG (1986) Treatment of theophylline intoxication. J Allergy Clin Immunol 78(4 Pt 2):811-817

60. Garella S (1988) Extracorporeal techniques in the treatment of exogenous intoxications. Kidney Int 33(3):735-754

61. Aitken ML, Martin TR (1987) Life-threatening theophylline toxicity is not predictable by serum levels. Chest 91(1):10-14

62. Lauterburg BH, Corcoran GB, Mitchell JR (1983) Mechanism of action of $N$-acetylcysteine in the protection against the hepatotoxicity of acetaminophen in rats in vivo. J Clin Invest 71(4):980991

63. Acetadote ${ }^{\mathrm{TM}}$ [Package Insert]. Cumberland Pharmaceuticals, Nashville, TN; January 2011

64. Prescott LF, Donovan JW, Jarvie DR et al (1989) The disposition and kinetics of intravenous $N$-acetylcysteine in patients with paracetamol overdose. Eur J Clin Pharmacol 37(5):501-506

65. Holdiness MR (1991) Clinical pharmacokinetics of $N$-acetylcysteine. Clin Pharmacokinet 20(2):123-134

66. Soldini D, Zwahlen H, Gabutti L (2005) Pharmacokinetics of $N$ acetylcysteine following repeated intravenous infusion in haemodialysed patients. Eur J Clin Pharmacol 60(12):859-864

67. Wagner HW Jr, Braunwald E (1956) The pressor effect of the antidiuretic principle of the posterior pituitary in orthostatic hypotension. J Clin Invest 35(12):1412-1418

68. Kirk CJ, Michell RH (1981) Phosphatidylinositol metabolism in rat hepatocytes stimulated by vasopressin. Biochem J 194(1):155165

69. Levine SD, Schlondorff D (1984) The role of calcium in the action of vasopressin. Semin Nephrol 4:144-158

70. Fox A (1988) Vascular vasopressin receptors. Gen Pharmacol 19 (5):639-645

71. Hirata Y, Hayakawa H, Kakoki M et al (1997) Receptor subtype for vasopressin-induced release of nitric oxide from rat kidney. Hypertension 29(1 Pt 1):58-64

72. Evora P, Pearson P, Schaff H (1993) Arginine vasopressin induces endothelium-dependent vasodilatation of the pulmonary artery.V1-receptor-mediated production of nitric oxide. Chest 103(4):1241-1245

73. Martinez M, Vila J, Aldaroso M et al (1994) Relaxation of human isolated mesenteric arteries by vasopressin and desmopressin. Br J Pharmacol 113(2):419-424 
74. Suzuki Y, Satoh S, Oyama H et al (1993) Regional differences in the vasodilator response to vasopressin in canine cerebral arteries in vivo. Stroke 24(7):1049-1053

75. Oyama H, Suzuki Y, Satoh S et al (1993) Role of nitric oxide in the cerebral vasodilatory responses to vasopressin and oxytocin in dogs. J Cereb Blood Flow Metab 13(2):285-290

76. Auslelo DA, Hall DH, Dayer JM (1980) Modulation of cyclic AMP-dependent protein kinase by vasopressin and calcitonin in cultured porcine renal L1C-PK1 cells. Biochem J 186(3):773780

77. Ausiello DA, Skorecki KL, Verkman AS, Bonvenlre JV (1987) Vasopressin signaling in kidney cells. Kidney Int 31 (2):521-529

78. Dousa TP, Valtin H (1976) Cellular actions of vasopressin in the mammalian kidney. Kidney Int 10(1):46-63

79. Hays RM, Frankl N, Ding G (1987) Effects of antidiuretic hormone on the collecting duct. Kidney Int 31(2):530-537

80. Knepper MA, Nielsen S (1993) Kinetic model of water and urea permeability regulation by vasopressin in collecting duct. Am J Physiol 265(2 Pt 2):F214-F224

81. Vavra I, Machova A, Holecek V et al (1968) Effect of a synthetic analogue of vasopressin in animals and in patients with diabetes insipidus. Lancet 1(7549):948-952

82. Richardson DW, Robinson AG (1985) Desmopressin. Ann Int Med 103(2):228-239

83. Dettloff RW, Touchette MA, Zarowitz BJ (1993) Vasopressorresistant hypotension following a massive ingestion of theophylline. Ann Pharmacother 27(6):781-784
84. Biberstein MP, Ziegler MG, Ward DM (1984) Use of betablockade and hemoperfusion for acute theophylline poisoning. West J Med 141:485-490

85. Kearney TE, Manoguerra AS, Curtis GP (1985) Theophylline toxicity and the beta-adrenergic system. Ann Intern Med 102 (6):766-769

86. Kempf, Rusterholtz T, Ber C et al (1996) Haemodynamic study as guideline for the use of beta blockers in acute theophylline poisoning. Intensive Care Med 22(6):585-587

87. Seneff M, Scott J, Friedman B, Smith M (1990) Acute theophylline toxicity and the use of esmolol to reverse cardiovascular instability. Ann Emerg Med 19(6):671-673

88. Gray R (1988) Managing critically ill patients with esmolol - an ultrashort-acting beta-adrenergic blocker. Chest 93(2):398-403

89. Price KR, Fligner DJ (1990) Treatment of caffeine toxicity with esmolol. Ann Emerg Med 19(1):44-46

90. Sheppard D, DiStefano S, Byrd RC (1986) Effects of esmolol on airway function in patients with asthma. J Clin Pharmacol 26 (3):169-174

91. Gaar GG, Banner W Jr, Laddu AR (1987) The effects of esmolol on the hemodynamics of acute theophylline toxicity. Ann Emerg Med 16(12):1334-1339

92. Goldberg MJ, Spector R, Mille G (1986) Phenobarbital improves survival in theophylline-intoxicated rabbits. J Toxicol Clin Toxicol 24(3):203-211

93. Hoffman A, Pinto E, Gilhar D (1993) Effect of pretreatment with anticonvulsants on theophylline-induced seizures in the rat. J Crit Care 8(4):198-202 